\title{
TARI OREK-OREK SEBAGAI IMPLEMENTASI PENDIDIKAN KARAKTER BERBASIS KEARIFAN LOKAL PADA SISWA SEKOLAH DASAR DI KABUPATEN NGAWI
}

\author{
Hartini \\ Program Studi Pendidikan Guru Sekolah Dasar, Universitas PGRI Madiun \\ hartini@unipma.ac.id \\ Hendra Erik Rudyanto \\ Program Studi Pendidikan Guru Sekolah Dasar, Universitas PGRI Madiun \\ hendra@unipma.ac.id
}

\begin{abstract}
Abstrak
Peningkatan mutu pendidikan karakter perlu dilakukan dalam segala aspek termasuk melalui konteks budaya. Penelitian ini bertujuan untuk mendeskripsikan implementasi pendidikan karekter berbasis kearifan lokal melalui tari Orek-Orek. Pendekatan penelitian yang digunakan adalah penelitian kualitatif deskriptif. Tempat penelitiannya adalah SDN Paron dan SDN Kedungputri 1 Kabupaten Ngawi. Teknik pengumpulan data meliputi studi dokumentasi, observasi dan wawancara. Teknik analisis data meliputi data reduction, data display, dan conclusion drawing/verification. Hasil penelitian menunjukkan bahwa Tari Orek-Orek tetap eksis sampai saat ini karena sinergi dan rutin dilakukan dalam berbagai event dan pembelajaran di sekolah. Karakter dalam tari Orek-Orek yang relevan bagi siswa diantaranya disiplin, lemah lembut, tanggung jawab, dan telaten. Kearifan lokal ini selalu terjaga karena sering ditampilkan dalam berbagai kegiatankegiatan besar misalnya perayaan HUT Kabupaten Ngawi. Tidak sampai disitu pemerintah daerah Kabupaten Ngawi juga sering mengadakan pelatihan-pelatihan atau workshop bagi guru SD, sehingga nantinya akan ditularkan kepada siswa disekolahnya.
\end{abstract}

Kata Kunci: Tari Orek-Orek, Karakter, Sekolah Dasar.

\begin{abstract}
Improving the quality of character education needs to be done in all aspects including through cultural contexts. This study aims to describe the implementation of character education based on local wisdom through OrekOrek dance. The research approach used is descriptive qualitative research. His research sites are Paron Elementary School and Kedungputri 1 Elementary School, Ngawi District. Data collection techniques include study documentation, observation and interviews. Data analysis techniques include data reduction, data display, and conclusion drawing / verification. The results of the study show that the Orek-Orek dance still exists today because of the synergy and routine carried out in various events and learning in
\end{abstract}


schools. The characters in Orek-Orek dance that are relevant for students include discipline, gentle, responsibility, and painstaking. This local wisdom is always maintained because it is often displayed in various major activities such as the celebration of Ngawi Regency's Anniversary. Not only that, the Ngawi Regency government also often held trainings or workshops for elementary school teachers, so that later it would be transmitted to students in their schools.

Keywords: Orek-Orek Dance, Character, Primary School

\section{A. Pendahuluan}

Pendidikan karakter merupakan objek yang saat ini paling diperhatikan di kalangan pendidikan modern. Sebagai fakta, pendidikan karakter menjadi semakin populer dalam kebijakan pendidikan saat ini dan dipraktikan di banyak negara- negara maju maupun berkembang sebagai titik acuan yang tak terhindarkan termasuk di negara Indonesia. Issue tersebut muncul mengingat banyak terjadi kemerosotan moral bangsa. Usaha telah dilakukan dalam berbagai aspek termasuk dalam pendidikan. Lickona (1992) menyatakan adanya moral absolute yang harus diajarkan kepada generasi muda agar mereka memahami dan melakukan mana yang baik dan menjauhi yang buruk. Oleh sebab itu pendidikan karakter menjadi penting untuk dilakukan.

Sebagai bagian utama yang tidak terpisahkan dengan pendidikan di Indonesia, Sekolah Dasar merupakan jenjang awal dalam frame wajib belajar 12 tahun. Oleh sebab itu, para siswa yang berada di dalam proses pendidikan dasar harus menghabiskan waktu selama 6 tahun dari usianya untuk mengenyam berbagai ilmu pengetahuan ke-SD-an baik intrakurikuler maupun ekstrakurikuler dan penekanan pendidikan karakter yang sangat komprehensif dan holistik. Sekolah dasar (SD) pada hakikatnya merupakan satuan atau unit lembaga sosial (social institution) yang diberi amanah atau tugas khusus (specific task) oleh masyarakat untuk menyelenggarakan pendidikan dasar secara sistematis, serta menjadi aspek strategis untuk menanamkan nilai-nilai yang positif terhadap siswa. karena pada prinsipnya pendidikan karakter yang baik harus melibatkan pengetahuan yang baik (moral knowing), perasaan yang baik atau loving good (moral feeling) dan perilaku yang baik (moral action) sehingga terbentuk perwujudan kesatuan perilaku dan sikap hidup peserta didik (Puskur Balitbang, 2011).

Pendidikan di SD dapat dikatakan sebagai pembentukan pondasi atau dengan kata lain pendidikan tersebut sesuai dengan kondisi apa adanya dari siswa SD. Maka dari itu, pendidikan harus berfungsi sebagai pemahaman atau penyadaran, pembiasaan, preventif, kuratif, serta fungsi penyaluran dan pengembangan (promotif). Pendidikan harus membantu untuk menyadarkan siswa akan kelebihan dan kelemahan diri, membentuk kebiasaan-kebiasaan maupun karakter yang baik, menyalurkan bakat dan minat, serta 
memberikan kesempatan dan peluang yang diberikan di lingkungannya. Pembelajaran juga harus memberikan ruang bagi siswa agar kemampuan kemampuan khususnya softskill siswa dapat berkembang (Rudyanto, 2013; Rudyanto, 2015).

Fungsi pendidikan yang salah satunya sebagai proses transformasi budaya, di mana dalam hal ini berfungsi untuk mewariskan budaya kepada generasi berikutnya. Misalnya bagaimana suatu masyarakat melestarikan adat dan kebiasaan yang dianggap baik kepada anak dan generasi penerusnya. Adapun fungsi tersebut juga berkenaan dengan bagaimana pendidikan mengubah nilainilai tertentu atau mengembangkan nilai-nilai baru yang dipandang sesuai dengan perkembangan masyarakat (Mikarsa, 2002). Selain itu, pembiasaan-pembiasaan untuk mengembangkan karakter siswa melalui konteks budaya mengingat merosotnya perilaku siswa yang terjadi baru-baru ini perlu dilakukan dan sifatnya urgen. (Rudyanto, 2018). Oleh sebab itu perlunya peningkatan mutu pendidikan karakter dalam segala aspek (Rudyanto, 2014).

Sementara itu, jika dikaitkan dengan realitas yang ada di lapangan dewasa ini, pergaulan siswa di tingkat sekolah dasar menjadi sangat rawan dengan dekadensi moral mengingat pesatnya perkembangan teknologi informasi berbasis digital. Sebagaimana diketahui, dekadensi moral yang kini tengah menjamur di kalangan masyarakat membuat siswa SD - salah satunya - korban ketiadaannya batas antara sesuatu yang baik dan buruk. Terlebih proses pendampingan dari orang tua dan keluarga yang merupakan madrasah pertama dan utama bagi seorang anak tidak bisa dilakukan selama 24 jam. Di sekolah pun saat siswa dititipkan oleh para orang tua untuk mendapatkan pendidikan juga tidak bisa menjadi jaminan untuk mampu mengondisikan mereka secara intensif. Bagaimanapun juga, tanggung jawab pribadi untuk tetap berada pada koridor yang berakhlak mulia harus ditanamkan dan diteladankan sejak dini dengan berbagai kegiatan positif baik di rumah maupun di sekolah.

Khusus untuk kegiatan di sekolah, ada banyak sekali kegiatan yang dapat diikuti oleh para siswa baik intra maupun ekstrakurikuler. Sebut saja selama ini kegiatan yang menjadi bagian dari pengembangan minat adalah ekstrakurikuler Pramuka, PMR, Polisi Kecil, Hadrah, Marching Band, Karya Ilmiah, dan lain-lain. Di wilayah Kecamatan Paron yang merupakan salah satu kecamatan di dari Kabupaten Ngawi terdapat salah satu pembiasaan yang dilakukan sebagai upaya untuk menjaga eksistensi budaya lokal, yakni tari Orek-orek. Sebagai warisan leluhur yang menambah kekayaan khazanah seni budaya lokal, tari Orek-orek memiliki kekhasannya sendiri jika dibandingkan dengan seni budaya yang ada di wilayah sekitar Kabupaten Ngawi seperti Dongkrek (Madiun) maupun Reog (Ponorogo).

Jika seni Dongkrek dan Reog telah banyak dikenal hingga mancanegara dan banyak mendapatkan respon positif dari para kritikus seni budaya, lain halnya dengan tari Orek- 
orek yang masih perlu banyak proses publikasi dan pemahaman untuk dapat dikatakan familiar. Di Kabupaten Ngawi sendiri, untuk melestarikan tarian ini, pemerintah daerah telah mengupayakan banyak cara. Di antaranya, pada tahun 2015 diselenggarakan tari Orek-orek massal di alun-alun Kabupaten Ngawi yang dilakukan oleh seluruh perwakilan siswa dan guru se-Kabupaten Ngawi demi memeringati Hari Kemerdekaan Indonesia. Bahkan, atas upaya dan kerja keras panitia penyelenggara akhirnya momentum tersebut juga mendapatkan sambutan yang positif dengan diraihnya rekor MURI dengan prestasi tarian tradisional massal. Tari Orek-Orek ini memiliki keunikan dimana tari ini diciptakan sebagai ekspresi atau bentuk luapan kegembiraan muda-mudi seusai bekerja berat (Mahardhika, 2015).

Sebagaimana seni di suatu wilayah yang kental dengan kearifan lokalnya, tari Orek-orek tentu juga memiliki sejarah, makna filosofis, hingga keunikan tersendiri. Hanya saja, karena peminatnya yang tidak banyak khususnya di kalangan generasi muda yang telah bayak terdominasi kecanggihan teknologi akhirnya para siswa khususnya di jenjang SD hanya bisa menarikan saja tanpa tahu makna setiap gerakan dan sejarahnya. Padahal, jika ditilik lebih dalam, kearifan lokal yang terkandung dalam tarian ini sangat baik dan adi luhung. Hal tersebut tentu akan sangat bermanfaat jika dipahami lebih lanjut oleh para guru dan siswa sehingga pendidikan karakter secara implisit juga dapat dipelajari dan dibiasakan melalui tarian ini. Oleh sebab itu, perlu digali lebih mendalam mengenai "Tari Orek-orek sebagai Implementasi Pendidikan Karakter Berbasis Kearifan Lokal pada Siswa Sekolah Dasar di Kecamatan Paron, Kabupaten Ngawi. “. Berdasarkan latar belakang yang telah dipaparkan maka rumusan masalah dalam penelitian ini adalah sebagai berikut.

1) Bagaimanakah sejarah dan bentuk penyajian Tari Orek-orek dari Kabupaten Ngawi?

2) Bagaimanakah eksistensi Tari Orek-orek ditinjau dari minat para siswa sekolah dasar di wilayah Kecamatan Paron, Kabupaten Ngawi?

3) Apakah jenis pendidikan karakter dalam tari Orek-orek yang relevan bagi para siswa sekolah dasar di wilayah Kecamatan paron, Kabupaten Ngawi?

4) Bagaimanakah pola kearifan lokal yang dapat diambil dari tari Orekorek?

5) Bagaimanakah menyosialisasikan pendidikan karakter dalam kaitannya dengan kearifan lokal bagi siswa sekolah dasar di Kecamatan Paron, Kabupaten Ngawi melalui tari Orek-orek?

\section{B. Metode}

1. Pendekatan dan jenis penelitian Pendekatan dalam penelitian ini adalah pendekatan kualitatif deskriptif. Noor (2011) menyatakan penelitian deskriptif merupakan penelitian yang berusaha mendeskripsikan suatu peristiwa, ataupun gejala serta kejadian yang terjadi. Pada penelitian deskriptif peneliti berusaha menarasikan 
kejadian yang menjadi pusat perhatian tanpa memberikan perlakuan khusus terhadap kejadian tersebut. usaha yang dilakukan untuk mendeskripsikan suatu objek, fenomena, atau suatu setting sosial terangkum dalam suatu tulisan yang berbentuk naratif. Pada penelitian ini, peneliti berusaha mendeskripsikan sejarah tari orekorek, perkembangan serta eksistensi tari Orek-Orek, karakter yang relevan untuk pendidikan karakter di sekolah dasar, kearifan lokal yang dapat diambil dalam pembelajaran, serta bagaimana sosialisasi pendidikan karakter melalui tari Orek-Orek.

2. Sumber Data

Data dalam penelitian ini adalah data komprehensif terkait tari orekorek dalam pendidikan karakter. Subyek penelitian ini adalah SDN Paron dan SDN Kedungputri 1 dimana narasumber yang dipilih adalah narasumber yang teribat langsung dalam kegiatan Tari OrekOrek di ke dua sekolah tersebut yaitu, kepala sekolah, guru, dan siswa.

3. Teknik pengumpulan data

Studi dokumentasi, observasi, dan wawancara dilakukan secara bertahap untuk mengumpulkan data yang dibutuhkan. Teknik triangulasi yang dilakukan ini dipilih untuk menjamin keabsahan data yang akan diperoleh. Keabsahan data diuji dengan triangulasi teknik yaitu mengecek data kepada sumber yang sama dengan teknik yang berbeda.

4. Teknik analisis data

Kegiatan analisis data dalam penelitian agar memperoleh data yang tuntas dan mencapai jenuh, maka aktivitas yang dilakukan meliputi data reduction, data display, dan conclusion drawing/verification perlu dilakukan (Miles dan Huberman, 1992). Proses analisis data yang dilakukan dalam penelitian ini secara eksplisit diilustrasikan pada Gambar 1.

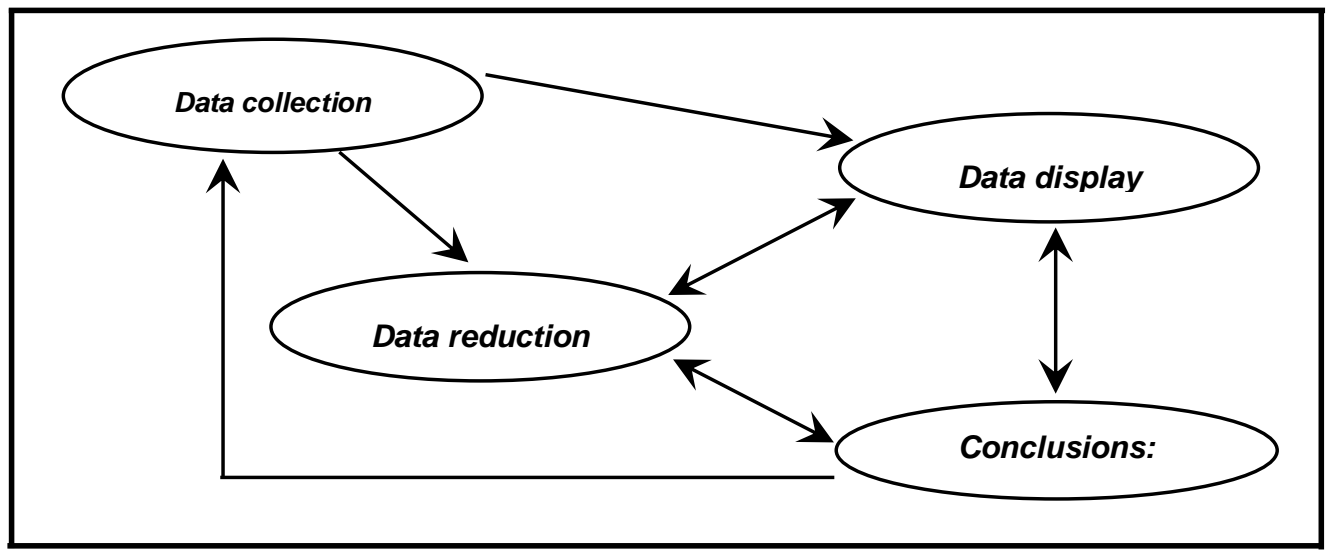

Gambar 1. Komponen dalam Analisis Data Interactive Model (Miles dan Huberman, 1992) 


\section{Hasil Penelitian dan Diskusi}

Berdasarkan kajian dan hasil wawancara yang dilakukan dengan kepala sekolah, guru di SDN Kedungputri 1 dan SDN Paron 1, Kabupaten Ngawi, serta melalui analisis data yang dilakukan, maka hasil penelitian diperoleh deskripsi tentang sejarah dan bentuk tari orekorek dari kabupaten Ngawi, eksistensi Tari Orek-orek ditinjau dari minat para siswa sekolah dasar di wilayah Kecamatan Paron, Kabupaten Ngawi, pendidikan karakter dalam tari Orekorek yang relevan bagi para siswa sekolah dasar di wilayah Kecamatan paron, Kabupaten Ngawi, kearifan lokal yang dapat diambil dari tari Orekorek, dan sosialisasi pendidikan karakter dalam kaitannya dengan kearifan lokal bagi siswa sekolah dasar di Kecamatan Paron kabupaten Ngawi melalui tari Orek-orek.

\section{Sejarah dan bentuk penyajian} Tari Orek-orek dari Kabupaten Ngawi.

\section{a. Sejarah}

Berdasarkan hasil wawancara dengan guru, dijelaskan bahwa tari orek-orek tercipta atau keberadaannya muncul pada tahun 1980 yang diciptakan oleh bu Sri Widajati. Tarian ini menggambarkan sebuah ungkapan kegembiraan masyarakat khususnya bagi pemuda pemudi. Pada masa itu para pemuda pemudi dipaksa untuk melakukan kerja rodi yang diperintahkan oleh pemerintah zaman Belanda di Ambarawa. Saat itu pemuda di Ngawi dan pemuda dari daerah lain dipaksa untuk membangun sebuah jembatan mulai Anyer sampai Panarukan. Kemudian setelah melakukan pekerjaannya, mereka melakukan berbagai pertunjukan seperti bermain kethoprak, ludruk dan menari bersama-sama sebagai huburan. Pada masa itu tari orekorek belum tercipta akan tetapi nama orek-orek sudah ada sejak dulu dikarenakan pemerintah Belanda mengatakan 'ini morakmarik bangsa". Mengapa disebut morak-marik dikarenakan asal pekerja rodi tersebut berasal dari berbagai daerah yang berbeda. dikarenakan lidah orang yang berbeda maka morak-marik menjadi morat-marit dan akhirnya menjadi orek-orek.

b. Bentuk penyajian

Bentuk penyajian dapat dikatakan sebagai bentuk kemasan atau penampilan dalam pertunjukan. Pada tari orek-orek, ditampilkan dalam bentuk kesenian tradisional berupa tari pergaulan yang merupakan perpaduan antara gerak tari dan nyanyian, kemudian diiringi tetabuhan yang cara memukulnya salah satunya dengan dikorek. Tari ini ditarikan oleh lakilaki dan perempuan berpasangan antara 4-10 orang. Akan tetapi diperbolehkan ditarikan hanya dengan penari perempuan saja.

2. Eksistensi Tari Orek-orek ditinjau dari minat para siswa sekolah dasar di wilayah Kecamatan Paron, Kabupaten Ngawi. 
Berdasarkan hasil wawancara dengan beberapa guru sekolah dasar di Kecamatan Paron, Kab. Ngawi menyatakan bahwa keberadaan tari orek-orek di Ngawi masih eksis. Hal ini ditunjukkan dengan adanya kegiatan menari di sekolah-sekolah dengan materi tari orek-orek. Selain itu sering diadakan pagelaran (pertunjukan), perlombaan dan festival. Bahkan tarian ini dilakukan rutin sebelum pembelajaran dimulai, dan juga masuk dalam kegiatan ekstrakurikuler. Kemudian ditinjau dari minat siswa, dipaparkan juga bahwa siswa sekolah dasar di wilayah kecamatan Paron khususnya di SDN Kedungputri 1 dan SDN paron 1 sangat antusias mengikuti kegiatan rutin menari.

Hal ini diperkuat melalui wawancara dengan beberapa siswa yang mengatakan bahwa mereka senang dan bangga dapat mengikuti kegiatan menari. Selain itu dapat mengetahui makna keseniannya, mengerti tradisi dan budaya dari daerah Ngawi. Dikatakan pula bahwa dengan mengikuti kegiatan rutin menari, maka badan menjadi sehat karena gerak terus dan mengeluarkan keringat. Minat siswa dalam kegiatan ini ditunjukkan pula melalui jumlah banyaknya siswa yang menari di halaman sekolah. Mereka rela untuk datang lebih pagi untuk mengikuti kegiatan ini. Keikutsertaannya yaitu siswa kelas satu sampai kelas enam. Orang tua juga mendukung, ditunjukkan dengan siswa dibekali sampur (selendang) untuk menari dan setiap hari mengantar kesekolah lebih awal.

Eksistensi juga dilihat melalui proses latihan. Sebelum dimulai tari orek-orek, siswa berkumpul dihalamn sekolah pada pukul 06.30 kemudian sebagai pemanasan yaitu melakukan senam otak kemudian dilanjutkan menari. Biasanya siswa yang sudah hafal ada pada barisan depan

\section{Pendidikan karakter dalam tari Orek-orek yang relevan bagi para siswa sekolah dasar di wilayah Kecamatan paron, Kabupaten Ngawi.}

Pembiasaan ini dilakukan untuk melatih dan mengembangkan karakter siswa. Hal tersebut mengisyaratkan pentingnya pengembangan karakter melalui konteks budaya mengingat merosotnya perilaku siswa yang terjadi baru-baru ini Pembelajaran di sekolah juga harus memfasilitasi siswa agar kemampuan dan softskill siswa dapat berkembang. Melalui tari orek-orek di SDN kedungputri dan SDN Paron, pendidikan karakter dapat diterapkann melalui :

a) Disipilin, ditunjukkan dengan harus mengikuti gerakan pakem dari penciptanya. Disiplin yang lain yaitu siswa datang pukul 06.30 untuk berbaris, kemudian harus mengikuti senam otak. Ini menunjukkan ketepatan waktu pada saat hadir di sekolah untuk mengikuti kegiatan yang diterapkan di sekolah.

b) Lemah lembut, ditunjukkan dengan menarikan tari orek-orek dengan perasaan yang lembut, dengan kata lain tidak semaunya sendiri atau dengan gerak yang kasar. Ini diwujudkan dalam keluwesan gerak yang diperagakan melalui mimik 
wajah, posisi badan dan pemakaian selendang yang benar.

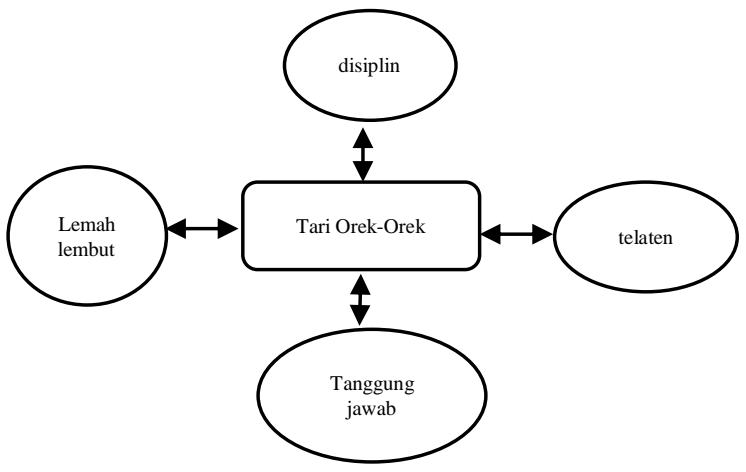

Gambar 2. Karakter tari Orek-Orek yang relevan bagi siswa SD

c) Telaten, ditunjukkan bahwa seorang penari harus telaten berlatih agar dapat menarikannya lebih baik. Dari sini pula dapat diartikan bahwa ketelatenan yang diwujudkan dengan kesabaran itu penting. Sebagai contoh, didalam menari pertama kali berlatih belum dapat mengikuti gerakannya, kemudian lama-kelamaan ia akan latihan sampai ia dapat menarikannya dengan lebih baik. Biasanya orang yang tidak telaten , ia akan menyerah dan putus asa, kemudian akan berhenti sampai disitu saja.

d) Tanggungjawab . ditunjukkan bahwa siswa dapat menjalankan/melakukan apa yang menjadi kewajibannya. Dalam kegiatan tari ini, siswa dilatih untuk menjadi seseorang yang dapat dipercaya untuk melaksanakan tanggungjawabnya. Sebagai contoh, pada barisan paling depan dalam menari adalah siswa yang sudah memiliki kemampuan yang lebih dibandingkan pada baris dibelakangnya. Nah, dengan hal ini maka siswa tersebut harus dapat mengkondisikan bahwa ia sudah dipercaya untuk memimpin dalam menari.

\section{Kearifan lokal yang dapat} diambil dari tari Orek-orek.

Melestarikan kebudayaan, dapat dikatakan sebagai bentuk untuk menjaga kepunahan dan dapat mempertahankannya. Sebagai salah satu kearifan lokal di daerah Ngawi yaitu tari orek-orek. Melalui tari ini , hal-hal yang dilakukan di SDN Kedungputri dan SDN Paron untuk melestarikannya yaitu dengan aktif mengikuti kegiatan rutin menari di sekolah, dan mengikuti berbagai even atau lomba dengan materi tari orek-orek.

\section{Sosialisasi pendidikan karakter dalam kaitannya dengan kearifan lokal bagi siswa sekolah dasar di Kecamatan Paron, Kabupaten Ngawi melalui tari Orek-orek.}

Pada saat latihan barisan harus lurus, gerakan seperti ini, tidak boleh seperti itu, ebetulnya sudah secara otomatis sebagai bentuk sosialisasi didalam praktiknya. Akan tetapi sosialisasi secara umumnya dapat ditunjukkan melalui sekolah khususnya di sekolah dasar. 


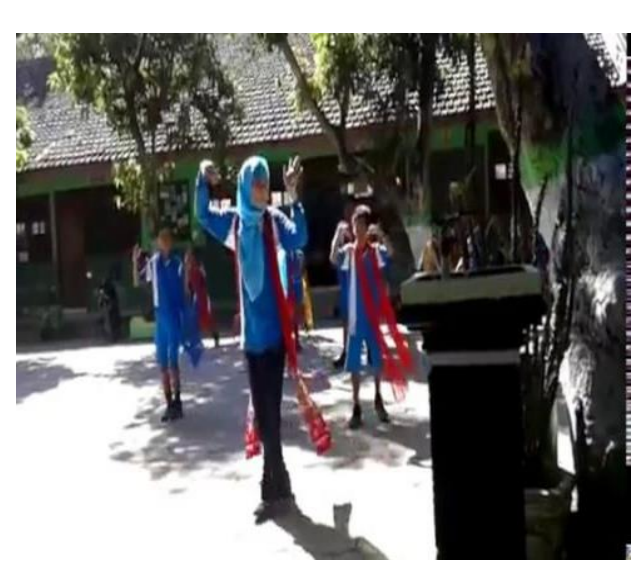

Sumber: foto diambil oleh peneliti Gambar 3. Pelaksanaan Tari Orek-Orek di Sekolah

Mengapa demikian, karena didalam tarian ini tidak hanya mengajarkan keindahan geraknya saja, akan tetapi juga mengajarkan pendidikan karakter. Pendidikan karakter melalui tari orek-orek dapat disosialisasikan dengan cara memperkenalkan sejarah tari ini muncul dan bentuk tariannya. Hal ini dapat juga dengan mengadakan pelatihan-pelatihan atau workshop bagi guru SD, sehingga nantinya akan ditularkan kepada siswa disekolahnya.

\section{Kesimpulan}

Dari penelitian ini, siswa dapat memahami sejarah dan bentuk penyajian Tari Orek-orek dari Kabupaten Ngawi, kemudian eksistensi Tari Orek-orek ditinjau dari minat para siswa sekolah dasar di wilayah Kecamatan Paron Kabupaten Ngawi. Kemudian jenis pendidikan karakter yang dapat diterapkan dalam tari Orekorek yang relevan bagi para siswa sekolah dasar di wilayah Kecamatan paron, Kabupaten Ngawi. Selain itu dapat diketahui juga bahwa pola kearifan lokal apa saja yang dapat diambil dari tari Orek-orek. Kemudian melalui pelatihan-pelatihan dan workshop dalam rangka untuk mensosialisasikan pendidikan karakter dalam kaitannya dengan kearifan lokal bagi siswa sekolah dasar di Kecamatan Paron.

\section{Daftar Pustaka}

Lickona, T. 1992. Educating for Character, How Our Schools can Teach Respect and Responsibility. New York: Bantam Book Company.

Pusat Kurikulum. 2009. Pengembangan dan Pendidikan Budaya dan Karakter Bangsa: Pedoman Sekolah. Jakarta: Puskur Kemendikbud.

Mahardhika, A.A. 2015. Tari OrekOrek Di Kabupaten Ngawi Tahun 1981-2014. Jurnal Avatara, Vol. 3 (3), hal. 534-545.

Mikarsa, dkk. 2002. Pendidikan Anak di SD. Jakarta: UT.

Miles, M.B., \& Huberman, A.M. 1992. Analisis Data Kualitatif Buku Sumber tentang Metode-Metode Baru. Terjemahan oleh Tjetjep Rohendi Rohidi. Jakarta: UI Press. 
Noor, J. 2011. Metodologi Penelitian Skripsi, Tesis, Desertasi, dan Karya Ilmiah. Jakarta: Kencana.

Rudyanto, H.E. 2013. Pengembangan kreativitas siswa sekolah dasar melalui pembelajaran matematika open-ended. Premiere Educandum: Jurnal Pendidikam Dasar dan Pembelajaran, 3(2), 184 - 192.

Rudyanto, H.E. 2014. Model discovery learning dengan pendekatan saintifik bermuatan karakter untuk meningkatkan kemampuan berpikir kreatif. Premiere Educandum: Jurnal Pendidikan Dasar dan Pembelajaran, 4(1), 41-48.

Rudyanto, H.E. 2015. Kemampuan berpikir kreatif dalam memecahkan masalah matematika open-ended ditinjau dari tingkat kemampuan matematika pada siswa sekolah dasar. Jurnal Pedagogia, Vol. 4(1), hal. 23- 33.

Rudyanto, H.E. 2018. Integrasi nilainilai karakter melalui pembelajaran matematika di sekolah dasar. Prosiding Konferensi Ilmiah Dasar, Universitas PGRI Madiun, Vol.1, hal. 34-43. 